Krystian M. Ziemski*, Mateusz Karciarz*

\title{
ZASADA DECENTRALIZACJI USTROJU TERYTORIALNEGO PAŃSTWA JAKO WARTOŚĆ W ŚWIETLE PRZEPISÓW KONSTYTUCJI RP I PRAWA MIĘDZYNARODOWEGO
}

\section{Wprowadzenie}

Zasada decentralizacji jest jednym z elementów charakterystycznych współczesnego państwa prawa. Jako jeden z fundamentów ustroju państwa przyjęta została także przez prawodawcę polskiego, który wyraził ją wprost w art. 15 ust. 1 Konstytucji RP. Wskazano w nim, że: „Ustrój terytorialny Rzeczypospolitej Polskiej zapewnia decentralizację władzy publicznej”. Pojęcie decentralizacji powiązano zatem w Konstytucji RP z podziałem terytorialnym, a więc decentralizacja w tym ujęciu oznacza decentralizację terytorialną.

Samo pojęcie decentralizacji znane jest nauce prawa administracyjnego i konstytucyjnego, w zasadzie nie budząc sporów co do jego istoty. Oznacza ono rozproszenie zadań i kompetencji niezbędnych do ich realizacji pomiędzy różne podmioty administrujące. Rozproszenie

* Krystian M. Ziemski - doktor habilitowany nauk prawnych, profesor UAM, Katedra Prawa Administracyjnego i Nauki o Administracji, Uniwersytet Adama Mickiewicza w Poznaniu.

** Mateusz Karciarz - Katedra Prawa Administracyjnego i Nauki o Administracji, Uniwersytet Adama Mickiewicza w Poznaniu. 
to nie może być rozpatrywane jedynie w sferze faktów, a więc faktycznego wyposażenia różnych podmiotów w zadania i kompetencje, które w każdej chwili mogą być ich pozbawione, lecz w sferze prawnej. Odbywać się ono bowiem musi w rezultacie działań prawodawcy, a więc $\mathrm{w}$ drodze ustanowienia stosownych przepisów prawa powszechnie obowiązującego albo działań podejmowanych na podstawie przepisów prawa w zakresie i w sposób nim określony. Charakterystyczne jest przy tym to, że podmioty, którym powierzono zadania, wyposażone być muszą w prawem chronioną sferę samodzielności w zakresie ich realizacji. Nie może to oznaczać oczywiście pełnej swobody w tym zakresie, ponieważ realizacja zadań publicznych, również z wykorzystaniem władztwa publicznego, odbywać musi się pod nadzorem państwa. Kolejną istotną cechą decentralizacji jest zatem określenie przez prawodawcę podmiotów kompetentnych do sprawowania w imieniu państwa nadzoru nad podmiotami wykonującymi powierzone zadania, określenie dopuszczalnych środków (form) wpływania na podmioty realizujące zadania publiczne, ich działalność czy też rezultaty tej działalności, oraz kryteriów, w oparciu o które weryfikowana jest działalność tych podmiotów. Stąd też nadzór ten kwalifikowany jest jako tzw. nadzór weryfikacyjny, z założenia wykluczający możliwość wydawania podmiotom zdecentralizowanym wiążących poleceń co do sposobu załatwiania określonej sprawy czy poszczególnych spraw, bądź podejmowanie działań ograniczających czy wręcz wykluczających swobodę podejmowania przez nie rozstrzygnięć. Takie działanie jest bowiem charakterystyczne dla administracji scentralizowanej.

Od strony techniczno-organizacyjnej pojęcie decentralizacji, a więc i zasady decentralizacji, jest wypełnione treścią w sposób niepozostawiający większych wątpliwości. Jednak od strony aksjologicznej, a więc wartości, jakie mają być przez aparat państwowy i podmioty zdecentralizowane realizowane, czy też do realizacji których zgodnie z normatywnie pojmowaną zasadą decentralizacji należy dążyć, wymagają doprecyzowania czy wręcz wypełnienia jej treścią. Prawodawca konstytucyjny zawarł w tym zakresie wyraźne wskazanie nie tylko w art. 15 i 16 Konstytucji RP, ale także w całym szeregu innych przepisów, zwłaszcza zawartych w rozdziale VII Konstytucji RP, zatytułowanym „Samorząd terytorialny”. 
Zaakcentować należy tutaj w pierwszej kolejności treść art. 15 Konstytucji RP, z którego wynika wprost nie tylko oparcie ustroju terytorialnego na zasadzie decentralizacji (ust. 1), ale także na kryteriach, z uwzględnieniem których tworzone są jednostki samorządu terytorialnego (ust. 2). W dalszej kolejności wskazać należy za prawodawcą konstytucyjnym art. 16 Konstytucji RP, określający istotę samorządu jako wspólnotę (korporację) mieszkańców danego terenu (a więc są to mieszkańcy oraz zajmowany przez nich teren) oraz wskazany w ust. 2 tego artykułu inny doniosły element decentralizacji, tj. sprawowanie przez samorządy części władzy publicznej, i to części istotnej, a nadto wykonywanej w imieniu własnym i na własną odpowiedzialność.

Wyznacznikiem skali zadań, które powierzone mają być samorządom, jest zasada subsydiarności (pomocniczości), którą sprowadzić można do dyrektywy: jak najmniej państwa w państwie. Wszystkie sprawy, z którymi mogą sobie poradzić samorządy, a więc społeczności lokalne, przekazane powinny być do ich gestii. Sprawy o znaczeniu lokalnym pozostawione mają być do załatwiania społecznościom, których dotyczą. Wyłącznie sprawy, z którymi nie mogłyby sobie poradzić bądź realizacja których wykracza poza obszar ich działania, powierzone mogą być jednostkom samorządowym stopnia wyższego ${ }^{1}$, a dopiero sprawy o charakterze wykraczającym poza ramy samorządu regionalnego stanowić powinny przedmiot działalności państwa jako takiego.

Przywykliśmy do wskazywania, że zasada subsydiarności jest wyrazem czy też jednym $z$ aspektów zasady decentralizacji ustrojowej państwa. Wyrazem tego ma być zakaz odbierania jednostkom samorządu terytorialnego powierzonych im zadań. Wnosić stąd można, że zasada subsydiarności jest instrumentalna dla zasady decentralizacji ustrojowej. Pomija się w ten sposób istotny fakt, że zasada subsydiarności, i to w wyraźnym powiązaniu z ustrojem terytorialnym pań-

${ }^{1}$ Określeniem stopnia wyższego posługujemy się z pełną świadomością braku hierarchicznej zależności pomiędzy poszczególnymi jednostkami samorządu terytorialnego działającymi czy to na szczeblu lokalnym, czy to na szczeblu regionalnym wyłącznie z uwagi na brak aparatury pozwalającej lepiej oddać istotę tego zagadnienia. 
stwa, wyrażona została w Konstytucji RP już w jej preambule jako jedna z wartości najbardziej doniosłych, podlegających szczególnej ochronie, do realizacji której należy dążyć przed innymi doniosłymi wartościami. Płynie stąd wniosek, że to zasada decentralizacji jest instrumentalna w stosunku do zasady subsydiarności, stanowiąc jeden z najważniejszych jej przejawów.

Nie może budzić wątpliwości, że ujęcie tej wartości w preambule Konstytucji RP nie stanowi pustej deklaracji, lecz wyraźny nakaz jej realizacji. Płynie stąd wniosek, że na państwie, jego organach, w tym zwłaszcza na władzy ustawodawczej, spoczywa obowiązek nie tylko niepozbawiania czy choćby ograniczania samorządu w jego kompetencjach, lecz obowiązek dążenia do tego, aby poszerzać możliwości finansowe, organizacyjne oraz inne samorządów terytorialnych celem umożliwienia im przejmowania kolejnych zadań. Zgodnie z zasadą subsydiarności obowiązkiem państwa jest podejmowanie działań poszerzających potencjał wykonawczy samorządu oraz zakres jego samodzielności. Jednym z podstawowych obowiązków państwa jest przy tym nie tyle pozorowanie powierzenia samorządom zadań, ile stworzenie rzeczywistej możliwości ich samodzielnego wykonywania na własną odpowiedzialność, z zapewnieniem państwu jedynie możliwości wkraczania za pośrednictwem organów nadzoru, z zastosowaniem prawem przewidzianych środków, i to wyłącznie w stwierdzonych przypadkach naruszenia prawa.

Katalog środków mających gwarantować samodzielność samorządów w realizacji ich zadań, za które ponoszą one odpowiedzialność, formułowany jest w doktrynie i w orzecznictwie sądowoadministracyjnym licznych współczesnych państw. Katalog ten znalazł swoje odzwierciedlenie w EKSL. Pobieżnie tylko sygnalizując to zagadnienie, wskazać należy na takie elementy budujące czy stanowiące podstawę rzeczywistej możliwości realizacji zadań przez samorządy, jak:

- wyposażenie jednostek samorządu terytorialnego w odrębną od państwa osobowość zarówno prawa publicznego, jak i prywatnego;

- posiadanie pochodzących $\mathrm{z}$ wyborów własnych organów uchwałodawczych i wykonawczych dysponujących własnym aparatem pomocniczym; 
- wyposażenie w środki finansowe adekwatne do skali powierzonych zadań;

- swoboda zrzeszania się;

- nadzór sprawowany wyłącznie przez wyraźnie wskazane organy przy pomocy wyraźnie zdefiniowanych środków stosowanych w stwierdzonych przypadkach naruszenia prawa (kryterium nadzoru - legalność);

- zapewnienie samorządom sądowej ochrony przed nadmierną ingerencją ze strony organów nadzorczych.

\section{Konstytucyjne podstawy decentralizacji ustroju terytorialnego państwa}

Jak już wskazano, podstaw prawnych skonstruowania państwa w oparciu o zasadę decentralizacji władzy publicznej upatrywać należy w szczególności w art. 15 Konstytucji RP. Jej rozwinięcie, odnośnie do ustroju terytorialnego państwa, zawarte zostało przez ustrojodawcę w art. 16 Konstytucji RP. Zgodnie z ust. 1 tego przepisu ogół mieszkańców jednostek zasadniczego podziału terytorialnego stanowi z mocy prawa wspólnotę samorządową. Natomiast w ust. 2 wskazano, że samorząd terytorialny uczestniczy w sprawowaniu władzy publicznej. Przysługującą mu w ramach ustaw istotną część zadań publicznych samorząd wykonuje w imieniu własnym i na własną odpowiedzialność.

Przypomnieć należy, że organy samorządu terytorialnego nie są jedynymi zdecentralizowanymi podmiotami władzy publicznej. W obecnym ustroju Rzeczypospolitej Polskiej zdecydowano bowiem, że decentralizacja władzy publicznej opiera się również na funkcjonowaniu innych rodzajów samorządów (czy też szerzej: korporacji prawa publicznego), o czym stanowi art. 17 Konstytucji RP². Zważywszy jednak

2 Art. 17 Konstytucji RP:

„1. W drodze ustawy można tworzyć samorządy zawodowe, reprezentujące osoby wykonujące zawody zaufania publicznego i sprawujące pieczę nad należytym wykonywaniem tych zawodów w granicach interesu publicznego i dla jego ochrony. 
na przedmiot niniejszego opracowania, zajmiemy się w nim analizą regulacji prawnych dotyczących samorządu terytorialnego jako podstawowej postaci realizacji zasady decentralizacji państwa.

W powyższym zakresie istotne są rozważania Trybunału Konstytucyjnego, który w jednym ze swoich wyroków zauważył, że pojęcie decentralizacji jest pojęciem niejednoznacznym w kontekście wieloszczeblowej struktury samorządu terytorialnego. Jak wskazał Trybunał, niektóre uprawnienia przysługujące samorządowi stanowią zadania i kompetencje przekazane samorządowi terytorialnemu w procesie decentralizacji, skoncentrowane są jednak na szczeblu ponadgminnym, powiecie czy województwie. Konstytucja RP w art. 15 ust. 2 uprawnia ustawodawcę do kształtowania zasadniczego podziału terytorialnego państwa, obejmującego także jednostki inne niż gmina. Zdaniem Trybunału Konstytucyjnego Konstytucja RP w art. 15 ust. 2 nie wyklucza dopuszczalności skupienia przekazanych samorządowi uprawnień na tym szczeblu zasadniczego podziału terytorialnego państwa, na którym zostanie zapewniona „zdolność ich wykonywania”. Ta właśnie zdolność stanowi istotną wartość konstytucyjną, bez której decentralizacja władzy publicznej traci swoje znaczenie jako zasadnicza podstawa ustroju demokratycznego i zaczyna temu ustrojowi zagrażać ${ }^{3}$.

W związku z tym, że ustrojodawca w przepisach Konstytucji RP w sposób generalny wskazał wyłącznie na fakt konieczności zapewnienia decentralizacji władzy publicznej, uznać należy, że ów wymóg w pierwszej kolejności skierowany jest do ustawodawcy, który powinien rozdzielać kompetencje $\mathrm{w}$ drodze stanowionych ustaw $\mathrm{w}$ taki sposób, aby jednoznacznie można było przesądzić, które z tych kompetencji przypisane są organom państwa, a które zdecentralizowanym organom władzy publicznej, z uwzględnieniem, że działają one na różnym poziomie podziału terytorialnego. Linia rozgraniczająca

2. W drodze ustawy można tworzyć również inne rodzaje samorządu. Samorządy te nie mogą naruszać wolności wykonywania zawodu ani ograniczać wolności podejmowania działalności gospodarczej."

${ }^{3}$ Wyrok TK z 18.02.2003 r., K 24/02, OTK-A 2003/2, poz. 11. 
powinna uwzględniać wspominaną już, wyrażoną w preambule Konstytucji RP, zasadę pomocniczości, zgodnie z którą zadania o charakterze lokalnym powinny być realizowane przez lokalne społeczności ( $\mathrm{z}$ naciskiem na ich realizowanie przez organy samorządu terytorialnego), a państwo (organy władzy państwowej) powinno (powinny) skupić się na realizacji wyłącznie zadań o znaczeniu ogólnokrajowym.

Prawidłowe ukształtowanie przez prawodawcę przejawów decentralizacji ustroju terytorialnego państwa nie może pomijać również kwestii właściwego ustroju organów samorządu terytorialnego oraz środków zapewniających rzeczywistą możliwość samodzielnego wykonywania powierzonych zadań. Obejmuje to, jak już wspomniano, nie tylko przyznane przez państwo w odpowiedniej wysokości środki pieniężne pozwalające na realizację przysługujących (przyznanych, przypisanych) tym organom kompetencji w zakresie realizacji zadań publicznych.

O ile kwestia organów samorządu terytorialnego na mocy art. 169 Konstytucji $\mathrm{RP}^{4}$ pozostawiona została do uregulowania w sposób szczegółowy ustawodawcy oraz organom stanowiącym JST, które w drodze wydawania przepisów ustrojowych mogą wypełniać ustawowo zakreślone ramy, to zapewnienie jednostkom samorządu terytorialnego udziału w dochodach publicznych odpowiednio do przypadających im zadań gwarantowane jest już wprost przepisem art. 167 ust. 1 Konstytucji RP5 . Zwiększenie zakresu zadań realizowanych przez jednostki samorządu terytorialnego powinno odbywać

\footnotetext{
4 Art. 169 Konstytucji RP:
}

„1. Jednostki samorządu terytorialnego wykonują swoje zadania za pośrednictwem organów stanowiących i wykonawczych.

2. Wybory do organów stanowiących są powszechne, równe, bezpośrednie i odbywają się w głosowaniu tajnym. Zasady i tryb zgłaszania kandydatów i przeprowadzania wyborów oraz warunki ważności wyborów określa ustawa.

3. Zasady i tryb wyborów oraz odwoływania organów wykonawczych jednostek samorządu terytorialnego określa ustawa.

4. Ustrój wewnętrzny jednostek samorządu terytorialnego określają, w granicach ustaw, ich organy stanowiące."

5 Art. 167 ust. 1 Konstytucji RP:

„Jednostkom samorządu terytorialnego zapewnia się udział w dochodach publicznych odpowiednio do przypadających im zadań." 
się z jednoczesnym zapewnieniem JST środków finansowych, o czym pracodawca często zapomina. Zagadnienie to jest dostrzegane przez jednostki samorządu terytorialnego, które już niejednokrotnie występowały do Trybunału Konstytucyjnego o zbadanie zgodności z Konstytucją RP przepisów przekazujących do realizacji na szczeblu lokalnym nowe zadania publiczne. Jedną z ostatnich takich spraw przed Trybunałem była sprawa K 24/14' ${ }^{6}$ która jednak na skutek cofnięcia wniosku została umorzona postanowieniem z 11.04.2017 r. ${ }^{7}$ Analiza kierowanych do Trybunału Konstytucyjnego wniosków JST stanowić powinna dla prawodawcy wskazanie na występujący problem z prawidłowym określeniem przez ustawodawcę wysokości środków finansowych przekazywanych na realizację zadań publicznych, i to zarówno zadań własnych (a więc podstawowych zadań realizowanych przez JST o znaczeniu lokalnym), jak i zadań zleconych (tj. zadań przekazywanych do realizacji bądź to na podstawie ustawy, bądź też na podstawie stosownych porozumień zawieranych $\mathrm{z}$ organami administracji rządowej). Argumentacja przywołana we wnioskach powinna skłonić ustawodawcę do podjęcia odpowiednich działań, w tym szczegółowych analiz, mających na celu zbadanie prawidłowości i zasadności funkcjonowania obecnych regulacji prawnych w tym zakresie.

Co prawda zapewnienie odpowiednich środków nie musi każdorazowo przy zmianie zakresu zadań przez prawodawcę bądź też w sytuacji pojawienia się nowych zadań o znaczeniu lokalnym oznaczać przekazania dodatkowych środków finansowych. Podkreślić jednak należy, że prawodawca zapewnić powinien JST środki i majątek

${ }^{6}$ Przedmiotem skierowanej przez Radę Powiatu Nowosolskiego oraz rady pięciu gmin $\mathrm{z}$ tego powiatu sprawy, która miała być rozpatrywana przez Trybunał Konstytucyjny, był zarzut niekonstytucyjności przepisów ustawy z 13.11.2003 r. o dochodach jednostek samorządu terytorialnego (Dz.U. z 2018 r. poz. 1530 ze zm.) oraz przepisów ustaw szczególnych regulujących realizację poszczególnych zadań publicznych przez JST, w zakresie, w jakim nie uwzględniają one mechanizmów kompensujących utracone dochody i koszty dodatkowych zadań jednostek samorządu terytorialnego oraz nakładają na te jednostki nowe zadania bez zapewnienia środków na ich realizację, bądź też rozszerzają zakres zadań JST bez zapewnienia środków kompensujących wynikających stąd dodatkowych wydatków.

7 Postanowienie TK z 11.04.2017 r., K 24/14, OTK-A/2017, poz. 26. 
własny pozwalający na realizowanie zadań własnych, a przy tym słabszym JST - również środki uzupełniające celem zapewnienia możliwości realizacji tychże zadań na niezbędnym, minimalnym poziomie oraz środki zapewniające realizację zadań zleconych adekwatnie do ich skali. Nadmierne obciążenie JST zadaniami, w sposób nieadekwatny do przekazanych środków, uniemożliwia w konsekwencji prawidłową realizację zadań, a to $\mathrm{z}$ kolei stanowić może podstawę twierdzenia co do ich nieprawidłowej realizacji czy wręcz podstawę dla pozbawionego usprawiedliwionych podstaw twierdzenia, że samorząd nie może sobie z określonymi zadaniami poradzić. W konsekwencji doprowadzić to może do prób odbierania samorządom określonych zadań jako przerastających ich możliwości finansowe i organizacyjne. W świetle zasady subsydiarności działanie takie zakwalifikować należałoby jako niezgodne z Konstytucją RP, godzące w podstawy demokratycznego państwa prawa.

\section{Charakterystyka nadzoru nad działalnością zdecentralizowanych podmiotów administracji publicznej w świetle Konstytucji}

W świetle Konstytucji RP, a zwłaszcza jej art. 171, nadzór nad JST został ograniczony zarówno od strony podmiotowej, jak i przedmiotowej. Prawodawca konstytucyjny wyraźnie wymienił podmioty określane jako organy nadzoru nad JST, a także jasno wskazał, iż jedynym kryterium sprawowania nadzoru jest legalność. Zastrzeżenie to stanowić będzie podstawę dla dalszych analiz dotyczących regulacji w zakresie uprawnień nadzorczych bezsprzecznie wpływających na wykonywanie zadań przez samorządy oraz na zakres ich rzeczywistej samodzielności.

Gwoli przypomnienia tylko wskazać należy, że pojęcie nadzoru nie jest tożsame z pojęciem kontroli. Istotą nadzoru jest bowiem możliwość dokonania - co do zasady po uprzednio przeprowadzonej kontroli ${ }^{8}$

${ }^{8}$ Istotą kontroli jest wyłącznie porównanie zastanego stanu ze stanem pożądanym i wyciągnięcie z tego porównania odpowiednich wniosków, jednak bez możliwości władczej ingerencji w działalność kontrolowanego podmiotu. 
- władczego oddziaływania na podmiot, który temu nadzorowi jest poddawany. Kontrola jednak, co do zasady, jako instrumentalna w stosunku do nadzoru, służyć powinna stosowaniu odpowiednich środków nadzoru. Nie ma zatem usprawiedliwionych podstaw kontrola dokonywana $\mathrm{z}$ innych punktów widzenia niż legalność. Również kontrola sądowa działań administracji, a zwłaszcza administracji samorządowej, dokonywana jest tylko z punktu widzenia legalności. Mówiąc o kontroli sądowej, podkreślić jednak należy, iż jest ona sprawowana $z$ jednej strony nad działaniami administracji publicznej, z drugiej jednak strony ma ona zapewnić samodzielność samorządu terytorialnego w realizowaniu jego zadań na własną odpowiedzialność, a więc stanowić ma ochronę przed, niezgodną z Konstytucją RP i ustawami, ingerencją organów nadzoru w jego działalność. Dotyczy to także ochrony przed ingerencją w tę działalność przez organy niemające przymiotu organów nadzoru, bądź stosowaniem kryteriów nadzoru innych niż wyraźnie przewidziane Konstytucją RP, tj. legalność.

Istotą prawidłowo funkcjonującego zdecentralizowanego ustroju terytorialnego państwa jest właściwe skonstruowanie przepisów dotyczących nadzoru nad JST jako podmiotami zdecentralizowanymi z jednoczesnym zapewnieniem kontroli sądowej nad zgodnym $\mathrm{z}$ prawem stosowaniem środków nadzorczych. Jedną z cech charakterystycznych decentralizacji jest występowanie w jej ramach pomiędzy organami władzy państwowej a zdecentralizowanymi podmiotami administracji publicznej wspomnianego nadzoru weryfikacyjnego, opartego wyłącznie na kryterium legalności. Stanowi o tym przepis art. 171 ust. 1 Konstytucji RP, zgodnie z którym działalność samorządu terytorialnego podlega nadzorowi z punktu widzenia legalności.

Analiza poszczególnych przepisów ustawowych regulujących sposób funkcjonowania organów jednostek samorządu terytorialnego oraz sprawowanego nadzoru wskazuje jednak na szereg wątpliwości. Dotyczą one katalogu podmiotów mogących ingerować w działalność samorządu terytorialnego, jak i dopuszczalnych kryteriów ingerencji. 
Dla usystematyzowania wywodów przypomnieć należy, że zgodnie $\mathrm{z}$ art. 171 ust. 2 Konstytucji RP organami nadzoru nad działalnością jednostek samorządu terytorialnego są Prezes Rady Ministrów i wojewodowie, a w zakresie spraw finansowych - regionalne izby obrachunkowe. Jest to katalog zamknięty i nie ma żadnych konstytucyjnych podstaw dla jego poszerzania o jakiekolwiek inne organy bądź inne podmioty.

W aktualniej praktyce legislacyjnej zauważalna jest tendencja do wprowadzania na rzecz organów niewskazanych w Konstytucji RP jako organy nadzoru możliwości stosowania różnego rodzaju środków ingerencji w działalność jednostek samorządu terytorialnego, która rodzi wątpliwości natury konstytucyjnej. W tym zakresie wskazać można na instytucje zatwierdzania, uzgadniania lub opiniowania rozstrzygnięć organu JST przez inne organy (zob. np. art. 89 u.s.g. oraz analogiczne rozwiązania w pozostałych dwóch samorządowych ustawach ustrojowych, tj. ustawie o samorządzie powiatowym oraz ustawie o samorządzie województwa). Działanie takie stanowi swego rodzaju nadzór ex ante, który w pewnych przypadkach nie daje się pogodzić z zasadą decentralizacji państwa. Szereg przepisów prawa administracyjnego zarówno materialnego, jak i proceduralnego $\mathrm{w}$ wielu przypadkach dla ważności rozstrzygnięć organów JST wymaga uzyskania zatwierdzenia, uzgodnienia lub zaopiniowania przez inny organ. $Z$ punktu widzenia zasady samodzielności JST, nierozerwalnie związanej z zasadą decentralizacji ustroju terytorialnego państwa, problematyczne jest zwłaszcza takie działanie organów współdziałających, które ogranicza (a niekiedy wręcz uniemożliwia) samodzielne przesądzanie przez organy JST o kwestiach istotnych związanych z realizacją powierzonych zadań z wykorzystaniem przypisanych im kompetencji. W świetle art. 82 ust. 2 u.s.g. i odpowiednich przepisów u.s.p. oraz u.s.w. prawodawca może uzależnić ważność rozstrzygnięcia organu gminy (odpowiednio również powiatu i województwa) od zatwierdzenia, uzgodnienia lub wyrażenia opinii. Zarówno $\mathrm{w}$ orzecznictwie, jak i w doktrynie dość zgodnie przyjmuje się, że z wyłączeniem opinii jako aktu z istoty swej niewiążącego - zajęcie stanowiska określonej treści warunkuje ważność rozstrzygnięcia 
organu gminy. Zatwierdzenie oznacza, że bez aprobaty innego organu dla treści określonego rozstrzygnięcia nie będzie ono miało atrybutu ważności. Podobny skutek wywołuje brak uzgodnienia treści rozstrzygnięcia $\mathrm{z}$ innym organem. W przypadku zatem gdy zatwierdzenie bądź uzgodnienie dokonywane jest przez organ inny niż konstytucyjny organ nadzoru, a także gdy odmowa zatwierdzenia bądź uzgodnienia dokonana może być w oparciu o kryterium inne niż kryterium legalności, zrodzić się może pytanie o konstytucyjność takich rozwiązań.

Wątpliwe z punktu widzenia przepisów Konstytucji RP jest posługiwanie się przez ustawodawcę konstrukcją „pozytywnej opinii”. Jak wspomniano, opinia z istoty swej traktowana jest jako najłagodniejsza forma współdziałania, stanowiąc jedynie niewiążące ustosunkowanie się organu zajmującego stanowisko, które może być pominięte przez organ rozstrzygający. Określenie „opinia pozytywna” jest zakamuflowaną postacią władczego, wiążącego wpływania na treść rozstrzygnięcia, taką jak uzgodnienie czy zatwierdzenie, przy czym z założenia opinia taka nie ogranicza się do zajęcia stanowiska wyłącznie z punktu widzenia legalności.

Z punktu widzenia stosowania ww. przepisów w praktyce pojawiają się problemy z ustaleniem granicy pomiędzy będącą cechą zdecentralizowanego ustroju władzy publicznej zasadą samodzielności a dopuszczalnością ingerowania w działalność organów jednostek samorządu terytorialnego. W takim przypadku niekiedy, w odniesieniu do konkretnych regulacji, pojawiać się mogą zarzuty niewłaściwego stosowania przepisów dotyczących zatwierdzania, uzgadniania lub opiniowania rozstrzygnięć organów JST przez inne organy w celu wpływania na sposób działania organów JST w sposób ograniczający ich samodzielność. To z kolei może stanowić podstawę do formułowania zarzutu niezgodności takiego działania z przepisem art. 171 ust. 2 Konstytucji RP, który, podkreślmy to wyraźnie, jednoznacznie i wyczerpująco wymienia organy posiadające kompetencje organów nadzoru nad działalnością organów samorządu terytorialnego, a także określa dopuszczalne kryterium nadzoru. 
W powyższym kontekście nie należy zapominać o fakcie, że zdecydowana większość organów zajmujących stanowisko w danej sprawie (tj. zatwierdzających, opiniujących czy uzgadniających) to organy administracji rządowej. Wzmacnia to tylko w wielu przypadkach wątpliwości co do konstytucyjności ingerencji administracji rządowej w samodzielność JST. Przykładem takiej ingerencji w tym zakresie jest konieczność uzyskania przez organy gminy bądź powiatu (jako organy prowadzące szkołę publiczną określonego typu) zgody właściwego miejscowo kuratora oświaty (a więc organu rządowej administracji) na likwidację placówki szkolnej. Negatywna opinia organu, który nie jest jednym $\mathrm{z}$ konstytucyjnych organów nadzoru, może być wydawana z uwzględnieniem różnych kryteriów, a nie tylko kryterium legalności, i uniemożliwić JST racjonalne realizowanie zadań publicznych z zakresu oświaty.

Celem przykładu wskazać tutaj można także na regulacje dotyczące przystąpienia przez jednostkę samorządu terytorialnego do międzynarodowych zrzeszeń społeczności lokalnych i regionalnych. Odbywać się to może wyłącznie po uzyskaniu zgody w drodze decyzji administracyjnej wydanej przez ministra właściwego do spraw zagranicznych (zob. art. 4 ustawy z 15.09.2000 r. o zasadach przystępowania jednostek samorządu terytorialnego do międzynarodowych zrzeszeń społeczności lokalnych i regionalnych ${ }^{9}$ ).

Działania takie jednoznacznie wpływają na sposób realizowania przez JST określonych zadań publicznych i ograniczają samodzielność tych jednostek w zakresie podejmowania decyzji. Praktyki takie doprowadzić mogą do uczynienia samodzielności decyzyjnej JST jedynie fasadą, za którą skrywa się próba obarczenia odpowiedzialnością za realizację zadań jednostek samorządu terytorialnego, które nie mają możliwości decydowania o sposobie ich realizacji. W związku z tym postawić można pytanie, czy ww. uprawnienia nie mają już charakteru nadzoru nad działalnością JST, co wykracza poza konstytucyjnie wyznaczone ramy. Dotyczy to zarówno katalogu podmiotów, które sprawują funkcje nadzorcze, jak i kryterium

\footnotetext{
${ }^{9}$ Dz.U. Nr 91, poz. 1009 ze zm.
} 
legalności jako jedynego kryterium pozwalającego na stosowanie środków nadzoru. Umożliwienie wspomnianemu przykładowo ministrowi wyrażania zgody (bądź odmowy wyrażania takiej zgody) na przystąpienie konkretnej JST do międzynarodowych zrzeszeń społeczności lokalnych i regionalnych, podobnie jak wyrażenie pozytywnej opinii przez kuratora oświaty, uznać należy za środki o charakterze nadzorczym i to oparte na kryteriach wykraczających poza legalność (np. cele polityki zagranicznej państwa, co wynika chociażby z art. 10 ww. ustawy).

Powyższych uwag nie należy jednak żadną miarą odczytywać jako generalnej krytyki współdziałania jako stanowiącej niekonstytucyjną ingerencję w działania samorządu. Nie można pomijać wszak sytuacji, gdy np. opiniowanie czy inna forma współdziałania dotycząca rozstrzygnięć organów JST dokonywana jest przez inne organy tychże jednostek, a także sytuacji, gdy to konstytucyjne organy nadzoru otrzymały od ustawodawcy uprawnienia do opiniowania czy uzgadniania szeregu działań organów jednostek samorządu terytorialnego. Wskazać można by tutaj chociażby na wojewodę, który tego typu uprawnienia posiada np. wodniesieniu do projektu statutu związku, w stosunku do którego dokonuje uzgodnień (zob. m.in. art. 67 ust. 1a u.s.g. w zakresie procedury uchwalenia statutu związku międzygminnego oraz analogiczne regulacje w zakresie procedury uchwalenia statutów związków powiatów i powiatowo-gminnych oraz procedury zmiany tychże statutów). Z punktu widzenia przepisów Konstytucji RP takie rozwiązania nie budzą wątpliwości, a to tym bardziej, że działania wojewody w tym zakresie oparte są wyłącznie na kryterium legalności.

Co istotne, działania innych organów niż organy JST, które wpływają na sposób realizacji zadań publicznych oraz korzystania ze związanych z nimi kompetencji przez jednostki samorządu terytorialnego, podlegają kontroli ze strony sądów administracyjnych. Mechanizm ten jednak w sytuacji, gdy organ zajmujący stanowisko nie musi ograniczać się wyłącznie do kryterium legalności, może okazać się zawodny. 
Zasygnalizowane powyżej uwagi skłonić powinny ustawodawcę do refleksji nad potrzebą zweryfikowania zgodności stosowanych praktyk z Konstytucją RP.

\section{Wymóg decentralizacji ustroju terytorialnego państwa w świetle przepisów prawa międzynarodowego}

Jak uprzednio wskazano, zasada decentralizacji władzy publicznej stanowi podstawę prawidłowego funkcjonowania współczesnego demokratycznego państwa prawnego. Znajduje to odzwierciedlenie również w szeregu przepisów prawa międzynarodowego obowiązujących Rzeczpospolitą Polską. Za podstawowy akt prawny w tym zakresie uznać należy EKSL.

Na marginesie warto również wskazać na przepisy prawa międzynarodowego, które $z$ uwagi na brak ich ratyfikacji nie stanowią prawa powszechnie obowiązującego Rzeczpospolitą Polską - wyrażone w Europejskiej Karcie Samorządu Regionalnego oraz Światowej Deklaracji Samorządu Lokalnego ${ }^{10}$.

Już w preambule EKSL wskazano, że społeczności lokalne stanowią jedną z zasadniczych podstaw ustroju demokratycznego. O konieczności stworzenia zdecentralizowanych powiązań pomiędzy organami administracji (władzy) publicznej mówią konkretne przepisy EKSL. W tym zakresie najistotniejszą rolę odgrywa art. 4 ust. 3 EKSL. Zgodnie z tym przepisem: „Generalnie odpowiedzialność za sprawy publiczne powinny ponosić przede wszystkim te organy władzy, które znajdują się najbliżej obywateli. Powierzając te funkcje innemu organowi władzy, należy uwzględnić zakres i charakter zadania oraz wymogi efektywności i gospodarności”. Pomimo dużej ogólności postanowień EKSL wskazać należy, że w odniesieniu do zasady subsy-

${ }^{10}$ Więcej na ten temat zob. A. Skoczylas, W. Piątek, Komentarz do art. 15 Konstytucji [w:] Konstytucja RP, red. M. Safjan, L. Bosek, t. 1, Komentarz do art. 1-86, Warszawa 2016. 
diarności jej postanowienia nie pozostawiają dużego marginesu swobody co do rozumienia zasady. Wskazano bowiem jednocześnie, iż to przekazując zadania innym jednostkom niż JST na szczeblu podstawowym, brać należy pod uwagę zakres i charakter zadań, a uzasadnieniem dla ich przekazania innym podmiotom muszą być szczególne okoliczności. Zasadą jest zatem realizowanie zadań lokalnych przez podmioty zdecentralizowane.

Z uwagi na występującą w prawie Unii Europejskiej tzw. zasadę autonomii (również instytucjonalnej) państw członkowskich trudno znaleźć w prawie pierwotnym wyraźnie i jednoznacznie wyartykułowaną zasadę decentralizacji władzy publicznej państwa. Jak stanowi art. 4 ust. 2 Traktatu o Unii Europejskiej, Unia szanuje równość państw członkowskich wobec Traktatów, jak również ich tożsamość narodową, nierozerwalnie związaną z ich podstawowymi strukturami politycznymi i konstytucyjnymi, w tym w odniesieniu do samorządu regionalnego i lokalnego. Prawo pierwotne szanuje podstawowe funkcje państwa, zwłaszcza funkcje mające na celu zapewnienie jego integralności terytorialnej, utrzymanie porządku publicznego oraz ochronę bezpieczeństwa narodowego. Również w orzecznictwie Trybunału Sprawiedliwości Unii Europejskiej wskazuje się, że „każde państwo członkowskie może tak podzielić kompetencje wewnętrzne, włącznie z kompetencjami ustawodawczymi, jak uważa to za celowe, oraz wdrażać niewiążące bezpośrednio akty prawa wspólnotowego poprzez środki przyjęte przez władze regionalne lub lokalne, o ile ten podział kompetencji umożliwia właściwe wykonanie odpowiednich aktów prawa wspólnotowego"11.

W kontekście zasady decentralizacji wskazać jednak można, że w preambule Traktatu o Unii Europejskiej wyraźnie podkreślono znaczenie funkcjonowania samorządu terytorialnego, i to zarówno lokalnego, jak i regionalnego. W świetle wymowy regulacji traktatowych uznać należy, iż zasady państwa prawa, w tym zasady de-

${ }_{11}$ Wyrok TS z 16.07.2009 r., C-428/07, LEX nr 505799. 
centralizacji, zwłaszcza zaś decentralizacji terytorialnej, stanowią wartość podlegającą szczególnej ochronie przez państwa przynależne do wspólnoty.

\section{Próba wskazania zagrożeń dla realizacji zasady decentralizacji terytorialnej państwa}

W ostatnich latach coraz częściej zauważalna jest praktyka podejmowania prób osłabiania samorządów, a zwłaszcza samorządu terytorialnego, w zakresie jego uprawnień i kompetencji oraz w zakresie realizowanych przezeń zadań, co może być zagrożeniem dla wartości, jaką stanowi zdecentralizowany ustrój terytorialny państwa. Sprowadzają się one do przerzucania na samorząd kolejnych zadań bez jednoczesnego przekazywania na rzecz samorządu środków adekwatnych do ich skali. Nadto zmierzają one do zwiększania skali oddziaływania na samorządy realizujące określone zadania na ich ryzyko. Stawia to pod znakiem zapytania samodzielność realizacji tych zadań. Pojawiają się także tendencje jawnie centralistyczne, sprowadzające się do pozbawienia samorządu terytorialnego określonych kompetencji władczych przy jednoczesnym pozostawieniu odpowiedzialności za realizację tych na samorządach.

Za nieprawidłową praktykę uznać w szczególności należy dokładanie nowych zadań samorządom bez zapewnienia środków finansowych. Wskazać trzeba, że samo nakładanie na samorządy nowych zadań nie może być poczytywane za zjawisko negatywne. Zasada subsydiarności wymaga wręcz, aby państwo w miarę rozwoju samorządności umacniało zdolności organizacyjnych samorządów i przekazywało na rzecz JST kolejne zadania. Nie może się to jednak odbywać bez zapewnienia JST adekwatnych środków finansowych bądź też innych składników majątkowych zapewniających rzeczywistą możliwość realizacji przekazywanych zadań.

Kwestie finansowe związane z realizacją określonych zadań publicznych w ramach przyznanych w sposób zdecentralizowany kompetencji są współcześnie największym zagrożeniem dla wartości, jaką 
jest zasada decentralizacji ustroju terytorialnego państwa. Znajduje to odzwierciedlenie w braku aktualizacji wysokości środków finansowych przyznawanych $\mathrm{z}$ budżetu państwa na realizację zadań publicznych pomimo zmieniających się uwarunkowań gospodarczych i ekonomicznych związanych z tymi zadaniami, zwłaszcza w przypadku gdy wiąże się to ze wzrostem kosztów realizacji tych zadań. Potwierdzeniem istnienia takich problemów są wskazywane już w niniejszym opracowaniu sytuacje, które skłaniały samorządy do kierowania wniosków do Trybunału Konstytucyjnego o zbadanie zgodności z przepisami Konstytucji RP przepisów ustawowych stanowiących podstawę do wyliczania konkretnej wysokości środków przekazywanych jednostkom samorządu terytorialnego ${ }^{12}$.

Ostatnim ze współczesnych zagrożeń dla wartości, jaką jest zasada decentralizacji ustroju terytorialnego kraju, jest odbieranie samorządom zadań publicznych o znaczeniu lokalnym bądź regionalnym i przekazywanie ich realizacji organom administracji rządowej. Celem przykładu wskazać można na dokonywane w ostatnim czasie zmiany w zakresie funkcjonowania wojewódzkich funduszy ochrony środowiska i gospodarki wodnej (WFOŚiGW), które pierwotnie podporządkowane sejmikom poszczególnych województw (a więc organom władzy samorządowej), podporządkowano administracji rządowej, czy też zmiany dokonane nowelizacją ustawy o zbiorowym zaopatrzeniu w wodę i zbiorowym odprowadzaniu ścieków odbierającą szereg uprawnień dotychczas przypisanych gminom na rzecz organów administracji rządowej ${ }^{13}$.

12 Poza zakresem niniejszego opracowania jest problematyka finansowania realizacji zadań zleconych, która w praktyce stanowi niejednokrotnie bardziej problematyczne zagadnienie niż kwestia przyznawania z budżetu państwa odpowiedniej wysokości środków finansowych na realizację zadań własnych. Więcej na ten temat zob. m.in. A. Kudra, M. Karciarz, Niedofinansowanie zadań zleconych $w$ świetle wyzwań reformy samorzadowej [w:] O samorzadzie terytorialnym z okazji jego 25-lecia, red. A. Łaga, Bielsko-Biała 2015.

13 Ustawa z 27.10.2017 r. o zmianie ustawy o zbiorowym zaopatrzeniu w wodę i zbiorowym odprowadzaniu ścieków oraz niektórych innych ustaw (Dz.U. poz. 2180). 
W obu przypadkach pozbawiono samorządy instrumentów, przy pomocy których realizowały określone zadania, odpowiedzialność za ich realizację pozostawiając JST.

\section{Podsumowanie}

Dokonane jedynie w sposób sygnalny analizy prawa krajowego i prawa międzynarodowego wskazują, że wartość, jaką jest zasada decentralizacji ustroju terytorialnego kraju, ma doniosłe znaczenie dla prawidłowego funkcjonowania Rzeczypospolitej Polskiej jako współczesnego demokratycznego państwa prawnego. Pojawiające się jednak wątpliwości i nieprawidłowości w tym zakresie powinny stanowić dla ustawodawcy asumpt do podjęcia szeroko zakrojonych konsultacji, badań i analiz mających na celu przygotowanie kompleksowych raportów dotyczących przygotowania zmian, mających zapewnić zgodne z Konstytucją RP oraz umowami międzynarodowymi funkcjonowanie samorządu terytorialnego, zarówno lokalnego, jak i regionalnego.

\section{Bibliografia:}

Kudra A., Karciarz M., Niedofinansowanie zadań zleconych w świetle wyzwań reformy samorzadowej [w:] O samorzadzie terytorialnym z okazji jego 25-lecia, red. A. Łaga, Bielsko-Biała 2015

Skoczylas A., Piątek W., Komentarz do art. 15 Konstytucji [w:] Konstytucja RP, t. 1, Komentarz do art. 1-86, red. M. Safjan, L. Bosek, Warszawa 2016 